\title{
CORTICOSTEROID METABOLISM AND RHEUMATOID ARTHRITIS
}

\author{
BY \\ H. F. WEST* \\ Sheffield Centre for the Investigation and Treatment of Rheumatic Diseases
}

(RECEIVED FOR PUBLICATION MARCH 7, 1957)

Steroid research was begun at this Centre 6 years ago in the expectation that it would contribute to our knowledge of the pathogenesis of rheumatoid arthritis. Much has been learnt since then of the secretion and metabolism of the adrenocortical hormones in health and disease. The object of this paper is to take stock of the present position vis-à-vis rheumatoid arthritis.

Why should interest have been taken in the adrenal cortex and its secretions when it was already known that cortisone was neither a cure nor a form of replacement therapy for rheumatoid arthritis? The reasons why Philip Hench turned his attention to the adrenal cortex 10 years ago are as valid now as they were then. To-day's reasons may be summarized as follows:

\section{A. The Absence of Environmental Determinants}

The rheumatoid arthritic's environment has been studied in considerable detail (E.R.C., 1950), and no suggestion has emerged of the existence of any environmental prerequisite. A survey of rheumatoid arthritis around the world shows that it occurs under the most diverse conditions, no immune region or race having yet been discovered. It has often been repeated (without chapter and verse) that the disease is rare in the tropics, but in Ceylon it appears to be as common as in Great Britain irrespective of race (Fernando, personal communication).

\section{B. Reversibility of the Disease}

The disease is reversible and the only known happening that can effect a reverse is a physiological

\footnotetext{
* Part-time Nuffield Research Fellow, University of Sheffield.
}

change in the patient's metabolic processes (i.e. pregnancy). Pregnancy also favourably affects Addison's disease which is due to a deficiency in the tissues of adrenocortical hormones (see below).

\section{Adrenocortical Metabolism}

Studies of the metabolism of adrenocortical steroids and the effect of such steroids on rheumatoid arthritis, to be discussed below, lend support to the theory that they may play an important part in the manifestation of the disease.

\section{The Adrenal Hormones and their Metabolism}

Present-day knowledge of this subject is very considerable. No attempt will be made to review it except in so far as it is necessary to help answer the following pertinent questions to which we, as physicians interested in rheumatoid arthritis, need answers:

(1) Is the Secretion of the Adrenal Cortex qualitatively Abnormal in Rheumatoid Arthritis and What is the Normal Secretion?-From experiments on mammals and from the treatment of human beings with adrenocortical deficiency it appears that the secretion of the post-natal adrenal cortex can be replaced by cortisone or cortisol (hydrocortisone), and desoxycorticosterone or-perhaps better-aldosterone. It is thought that these hormones, given in the right proportion, and varied in amount according to the need of the individual, provide a complete replacement for the adrenal cortex. The other constituents of the adrenocortical secretion may be considered as by-products of the synthesis of the essential hormones mentioned above and/or vestiges of less useful hormones which were utilized 
in the remote past. This may prove to be the case, but it would be wiser to study the adrenocortical secretion completely, and not to assume that we can replace it so simply, until the results of prolonged replacement therapy have been assessed. As a result of the studies of numerous groups of investigators, some thirteen to seventeen steroids are thought to emerge from the adrenal vein (Pincus, 1955; Pincus and Romanoff, 1955). Cortisol and corticosterone make up approximately half, 5 to 10 per cent. are 17-ketosteroids (androstenedione and 11-hydroxyandrostenedione), and the rest including aldosterone are present in very small amounts (Simpson and Tait, 1955). Not all the steroids detected have been fully identified, and a reason for thinking that there may be unidentified steroids with physiological activity is the presence, in the adrenal cortical tissue, of specific steroidhydroxylating enzymes for which no purpose is known (Pincus, 1955).

It is only in exceptional circumstances that adrenal vein blood is available for study, and even then the quantities are small. In consequence we have no direct evidence of the normal or of any abnormal qualitative pattern of adrenocortical secretion. More evidence comes from studies of peripheral vein blood and from urine. In peripheral vein blood some fifty or so steroids have been detected (Pincus, 1955). From a study of their structure, and of the various transformations of steroids that occur in adrenal perfusion and incubation experiments, much has been deduced about the adrenocortical secretion (Dorfman, 1955). Even so, the question asked cannot be answered definitely for any disease, but it can be said that, so far, no steroid has been proved to be peculiar to any disease and that there is no proof that any normal steroid is missing in any particular disease. In urine the array of steroids is even greater, and the evidence of adrenocortical secretion that their study provides is more indirect and difficult to interpret. So far the same conclusion holds as for the peripheral vein blood.

(2) Is there a Quantitative Defect in the Secretion of the Adrenal Cortex in Rheumatoid Arthritis?

\section{(A) OF CoRTISOL}

Blood.-Methods are in use for estimating the level of cortisol circulating in plasma (Nelson and Samuels, 1952; Silber and Porter, 1954). Free and loosely protein-bound cortisol is extracted with chloroform, purified chromatographically, and measured by the Porter-Silber reaction (Porter and
Silber, 1950). In rheumatoid arthritics the levels found have fallen within the normal range and have shown the usual diurnal variation (Hill, Holley, Starnes, and Hibbett, 1956). It has only recently been recognized that the techniques in use are liable to be inaccurate and are capable of improvement (Gemzell, 1955; Lampe-Hintzen and Huis in't Veld, 1955; Marks and Leftin, 1954; Querido, Kassenaar, and Cats, 1955; Silber and Busch, 1956). When the extracts used are more thoroughly purified and due allowance is made for interfering chromogens the assays become less variable. No detailed results of the improved assays of such plasma "17-hydroxycorticosteroids" in rheumatoid arthritis and other diseases have as yet been published. When they are known it will still be necessary to find out whether they reflect the adrenal output of cortisol (see below). Renal failure, of course, modifies the interpretation of all blood and urinary measurements. Other methods are being developed for the assay of plasma cortisol (Sweat, 1955).

Cortisol that has been reduced and conjugated with glucuronic acid or sulphuric acid also circulates in the plasma. It may be extracted, hydrolysed, and measured by the Porter-Silber reaction (Bongiovanni, 1954; Klein, Papadatos, Fortunato, and Byers, 1955). So far knowledge of such assays is not sufficiently advanced to allow deductions to be made from them regarding the quantitative output of cortisol.

Urine.-As a result of a number of studies of the fate of intravenously-administered cortisol and $4 \mathrm{C}^{14}$ cortisol (Hellman, Bradlow, Adesman, Fukushima, Kulp, and Gallagher, 1954; Hellman, Bradlow, Frazell, and Gallagher, 1956; Migeon, Sandberg, Decker, Smith, Paul, and Samuels, 1956; Peterson and Wyngaarden, 1955, 1956), it can be concluded that the measurement in urine of conjugated 17-hydroxycorticosteroids does reflect, at least roughly, the adrenal output of cortisol in health and disease (provided there is no gross renal or hepatic disease). The 17-ketogenic steroid (17 KGS) assay (Norymberski, Stubbs, and West, 1953) and the assay of total 17-hydroxycorticosteroids (17(OH)CS) (Appleby, Gibson, Norymberski, and Stubbs, 1955), both developed at this Centre, measure some 40 to 45 per cent. of the conjugated metabolites of intravenously or orally administered cortisol that are known to appear in urine. Metabolites of certain other corticosteroids are also measured by these assays, but they are rarely present in other than trace quantities. The rare instances include the adreno-genital disorders and tumours of the adrenal cortex. During the last 
3 years 24-hr specimens from 124 rheumatoid arthritics not receiving steroid or ACTH therapy have been assayed for $17(\mathrm{OH}) \mathrm{CS}$ at the Centre.

TABLE I

24-HR URINARY OUTPUT OF 17-HYDROXYCORTICOSTEROIDS OF 124 PATIENTS WITH RHEUMATOID ARTHRITIS

\begin{tabular}{|c|c|c|c|c|c|}
\hline \multirow{3}{*}{$\begin{array}{c}\text { Sex } \\
\text { Female }\end{array}$} & \multirow{3}{*}{$\begin{array}{c}\begin{array}{c}\text { No. } \\
\text { of } \\
\text { Patients }\end{array} \\
68\end{array}$} & \multicolumn{4}{|c|}{ Output of Total 17-hydroxycorticosteroids } \\
\hline & & \multicolumn{2}{|c|}{$\begin{array}{c}\text { 24-hr Specimens } \\
\text { (mg.) }\end{array}$} & \multicolumn{2}{|c|}{$\begin{array}{l}\text { Amount per } 1 \mathrm{~g} . \\
\text { Creatinine (mg.) }\end{array}$} \\
\hline & & $\begin{array}{l}\text { Mean } \\
\text { S.D. } \\
\text { Scatter }\end{array}$ & $\begin{array}{l}10 \cdot 48 \\
2 \cdot 45 \\
5 \cdot 8-14 \cdot 8\end{array}$ & $\begin{array}{l}\text { Mean } \\
\text { S.D. } \\
\text { Scatter }\end{array}$ & $\begin{array}{l}10 \cdot 6 \\
2 \cdot 12 \\
6 \cdot 5-16 \cdot 3\end{array}$ \\
\hline Male & 56 & $\begin{array}{l}\text { Mean } \\
\text { S.D. } \\
\text { Scatter }\end{array}$ & $\begin{array}{l}13 \cdot 1 \\
3 \cdot 0 \\
5 \cdot 8-23 \cdot 2\end{array}$ & $\begin{array}{l}\text { Mean } \\
\text { S.D. } \\
\text { Scatter }\end{array}$ & $\begin{array}{l}9 \cdot 64 \\
2 \cdot 45 \\
5 \cdot 7-16 \cdot 5\end{array}$ \\
\hline Total & 124 & $\begin{array}{l}\text { Mean } \\
\text { S.D. } \\
\text { Scatter }\end{array}$ & $\begin{array}{l}11 \cdot 65 \\
2 \cdot 96 \\
6 \cdot 2-23 \cdot 2\end{array}$ & $\begin{array}{l}\text { Mean } \\
\text { S.D. } \\
\text { Scatter }\end{array}$ & $\begin{array}{l}10 \cdot 1 \\
2 \cdot 45 \\
5 \cdot 7-16 \cdot 5\end{array}$ \\
\hline
\end{tabular}

Table I shows that in each of 124 rheumatoid arthritis patients the output of $17(\mathrm{OH}) \mathrm{CS}$ falls well within the accepted normal range. Table II relates the daily output to age, severity of disease as judged by the erythrocyte sedimentation rate, and duration of disease. It is clear from these results that the adrenal output of cortisol is not low in rheumatoid arthritis, and that the disease, no matter how severe, does not constitute a "stress" to the hypothalamicadenohypophyseal centre that controls adrenocortical "glucocorticoid" secretions. (The adrenal output of cortisol $=\mathrm{mg}$. $17(\mathrm{OH}) \mathrm{CS} \times 2 \cdot 5$.) The assay procedures for urinary "17-hydroxycorticosteroids" (Reddy, 1954; Silber and Porter, 1954) may also reflect the output of cortisol when further elaborated to improve their accuracy (Hertoghe, Crabbe, Duckert-Maulbetsch, and Muller, 1955).

\section{(B) Of Corticosterone}

The ratio of cortisol to corticosterone present in adrenal vein blood has been shown to differ among mammals (Bush, 1953). As corticosterone has considerable "mineralo-corticoid" activity, there has been speculation whether an abnormal ratio of cortisol to corticosterone in man may be responsible for certain diseases. Very few observations have been made on human adrenal vein blood (Pincus and Romanoff, 1955; Sweat, 1955; Weichselbaum and Margraf, 1955). The measurement of the ratio in plasma has proved difficult, and so far the methods used have provided different figures for the normal (Bush and Sandberg, 1953; Morris and Williams, 1955; Nelson and Samuels, 1952; Sweat, 1955; Sweat, Abbott, Jeffries, and Bliss, 1953). If estimations of plasma corticosterone cannot yet answer the question, what of urinary assays? There is no known group-determination for the metabolites of corticosterone. The assays of Pettenkoffer chromogens in urinary steroid extracts has been proposed as such a measure, but it is not accepted as chemically specific for corticosterone in the circumstances. Corticosterone and some of its metabolites have been identified in urine and roughly measured with chromatographic techniques by a number of workers, but only recently has a hopeful technique for the quantitative assay of a specific metabolite (tetrahydrocorticosterone) been described (Gulyassy and Rinfret, 1956). The question as regards corticosterone still remains unanswered.

\section{(C) Of Aldosterone}

The concentration of aldosterone in the peripheral veinous blood of normal individuals has been measured (Simpson and Tait, 1955), but the amount found $(0.08 \mu \mathrm{g}$. per $100 \mathrm{ml}$.) is far too small to allow a practical routine assay. The assay of free and

TABLE II

24-HR URINARY OUTPUT OF 17-HYDROXYCORTICOSTEROIDS IN RHEUMATOID ARTHRITIC PATIENTS BY AGE GROUPS, BY GIVEN RATES OF ERYTHROCYTE SEDIMENTATION (AT THE TIME OF ASSAY), AND BY DURATION OF DISEASE

\begin{tabular}{|c|c|c|c|c|c|c|c|c|c|}
\hline \multicolumn{3}{|c|}{ Effect of Age } & \multicolumn{3}{|c|}{$\begin{array}{c}\begin{array}{c}\text { Effect of Erythrocyte Sedimentation Rate } \\
\text { (Wintrobe) }\end{array} \\
\end{array}$} & \multicolumn{4}{|c|}{ Effect of Duration of Disease } \\
\hline $\begin{array}{l}\text { Age Group } \\
\text { (yrs) }\end{array}$ & $\begin{array}{l}\text { No. of } \\
\text { Patients }\end{array}$ & $\begin{array}{l}\text { Mean Output } \\
\text { (mg.) }\end{array}$ & $\underset{(\mathrm{mm} . / \mathrm{hr})}{\text { E.S.R. }}$ & $\begin{array}{l}\text { No. of } \\
\text { Patients }\end{array}$ & $\begin{array}{l}\text { Mean Output } \\
\text { (mg.) }\end{array}$ & $\begin{array}{l}\text { Duration } \\
\text { (yrs) }\end{array}$ & $\begin{array}{c}\text { No. of } \\
\text { Patients }\end{array}$ & 1 & $\begin{array}{c}\text { Mean Output } \\
\text { (mg.) }\end{array}$ \\
\hline $\begin{array}{l}20-29 \\
30-39 \\
40-49 \\
50-59 \\
60-69 \\
70-79\end{array}$ & $\begin{array}{r}4 \\
22 \\
35 \\
38 \\
23 \\
3\end{array}$ & $\begin{array}{r}9 \cdot 8 \\
9 \cdot 4 \\
10 \cdot 7 \\
9 \cdot 5 \\
10 \cdot 6 \\
11 \cdot 8\end{array}$ & $\begin{array}{l}10-19 \\
20-29 \\
30-39 \\
40-49 \\
50-59 \\
60-69\end{array}$ & $\begin{array}{r}10 \\
19 \\
24 \\
22 \\
22 \\
5\end{array}$ & $\begin{array}{r}10 \cdot 4 \\
10 \cdot 0 \\
10 \cdot 0 \\
9 \cdot 9 \\
10 \cdot 2 \\
11 \cdot 3\end{array}$ & $\begin{array}{c}1 \\
2 \\
3 \text { and } 4 \\
5 \text { and } 6 \\
7,8 \text { and } 9 \\
10+\end{array}$ & $\begin{array}{l}14 \\
17 \\
18 \\
15 \\
18 \\
22\end{array}$ & & $\begin{array}{c}9 \cdot 16 \\
10 \cdot 0 \\
10 \cdot 6 \\
9 \cdot 8 \\
11 \cdot 2 \\
9 \cdot 2\end{array}$ \\
\hline
\end{tabular}


conjugated aldosterone in urine is difficult and timeconsuming, but somewhat similar results have been obtained by a number of workers (Avandano, Nelson, Crabbe, Ross, Renold, and Thorn, 1956; Gornall, Gwilliam, and Hall, 1956). The findings for the rheumatoid arthritics studied have been within the normal range (Venning, Beck, Dyrenfurth, and Giroud, 1955; Ward and Hench, 1955). (That the metabolites of aldosterone measured in urine do reflect output of aldosterone is an assumption as yet unproven.)

\section{(D) Of Other Adrenal Steroids}

When a secreting adrenocortical tumour is present, or the synthesis of adrenocortical hormones is grossly abnormal, as in the adrenogenital disorders, relatively large quantities are excreted of certain corticosteroid metabolites that are normally excreted in only very small amounts. In such cases it can be inferred that the precursors of these metabolites are secreted by the adrenal in excessive amounts. In rheumatoid arthritis, no such gross abnormal secretion has been found.

Minor excesses or deficiencies in the quantitative excretion of these corticosteroids metabolites, with the exception of 17-hydroxypregnanolone, have received little attention as yet. It was reported that 17-hydroxypregnanolone did not appear in the urine of normal individuals, but that it did occur in the urine of rheumatoid arthritics (Dobriner, Lieberman, Wilson, Dunham, Sommerville, and Rhoads, 1951). It has been shown at this Centre that 17-hydroxypregnanolone is excreted by normal individuals, and that the output of rheumatoid arthritics is within the normal range (Appleby, Gibson, and Norymberski, 1955).

Measurements of the adrenal output of 17-ketosteroids is confused by the presence in plasma or urine of similar ketosteroids derived from the metabolism of corticosteroids and testosterone. There is no assay from which it can be deduced with any certainty just what is the normal quantitative output of $17 \mathrm{KS}$ from the adrenal. When the secretion of the adrenal cortex is stimulated or suppressed, the quantity of 17-ketosteroids excreted in the urine rises and falls in company with the rise and fall of cortisol metabolites. Among rheumatoid arthritics given adrenal stimulation therany, the ratio of 17-ketosteroids to $17(\mathrm{OH}) \mathrm{CS}$ excreted varies a great deal (West, 1953-54). The increment of 17-KS excreted is clearly of adrenal origin, since no such rise occurs after the intravenous infusion of cortisol or corticosterone. Although variations in the ratio have been noted in non-rheumatoid subjects
(Forsham, Di Raimondo, Island, Rinfret, and Orr, 1955), it is a finding that requires further study.

(3) Is there a Relative Deficiency in the Output of Adrenocortical Steroids in Rheumatoid Arthritis?

At this Centre we have observed repeatedly that patients with rheumatoid arthritis who are really ill, with fever and very many painful, swollen joints, patients who in the common parlance would be considered severely "stressed", do not even have a high normal output of cortisol (as judged by the urinary output of total $17(\mathrm{OH}) \mathrm{CS}$ ). We cannot tell whether this is an abnormality or not until it is known just what metabolic disturbance should or should not call for an increased output of cortisol. Here is a serious gap in our knowledge of pituitary-adrenocortical function. If there is a defect in the pituitary-adrenal response to stress of the rheumatoid arthritic, that failure is likely to be found in the hypothalamic or pituitary response, since we have found no rheumatoid arthritic patient unresponsive to exogenous corticotropin. Adrenal stimulation therapy was given in 140 cases, and the clinical responses were confirmed by urinary steroid assays in every patient. There is no reason to think that rheumatoid arthritics fail to respond to those forms of stress (e.g. major surgery) that are known to cause an increased secretion of corticotropin. If corticotropin is given to severely ill rheumatoid arthritics, so as to raise the output of urinary $17(\mathrm{OH}) \mathrm{CS}$ to 30-35 mg. a day, their pain, fever, and "dis-ease" disappears. (In the 24 hours after major surgery we have observed outputs of $17(\mathrm{OH}) \mathrm{CS}$ of from 20 to $65 \mathrm{mg}$.) It is often said that this effect of the adrenocortical hormones on rheumatoid disease is merely one of a non-specific anti-inflammatory agent. With so little known of the nature of the inflammation of rheumatoid arthritis and of the mechanisms by which cortisol has its effects, this statement is, to say the least, non-contributory. Only one study of the effects of prolonged adrenal stimulation therapy controlled by corticosteroid assays has been published (West and Newns, 1955). The study, made at this Centre, has continued for a further two years and the results still suggest that the course of the disease is favourably affected. This lends support to the concept of there being a relative deficiency in the adrenocortical secretion.

(4) Is there an Abnormality in the Metabolism of the Adrenocortical Steroids in Rheumatoid Arthritis?

\section{(A) UTILIZATION}

The studies of the fate of intravenously administered cortisol and $4 \mathrm{C}^{14}$ cortisol, referred to above, 
have shown that the percentage recovery of the groups of cortisol metabolites in urine remain substantially unchanged whatever dose is given and whether the body is deficient or has an excess of circulating cortisol at the time. This has led to the idea that cortisol produces its characteristic effects without being used up. All that can strictly be inferred is that the part of the steroid nucleus (ring A) with the labelled carbon atom is still intact after passage through the body (Hellman and others, 1954; Barry, Eidinoff, Dobriner, and Gallagher, 1952). These findings still leave room for a variable amount of utilization to occur and for defects in utilization to exist. It may well be that the mechanism for the disposal of adrenocortical hormones deals with the major portion of the hormones secreted and that a relatively small amount takes part in connective tissue metabolism. Significant alterations in the tissue metabolites would not necessarily be detected in assays of groups of corticosteroid metabolites. For instance, a relative fall in the excretion of 11-oxygenated 17-ketosteroids has been found towards the end of pregnancy (Dobriner, Lieberman, Rhoads, and Taylor, 1948) and during surgical stress (Birke, Franksson, and Plantin, 1955). The welfare of the connective tissues may depend in part upon the amount of physiologically active cortisol made available to them (see below) and to their ability to bind the steroid in normal and diseased states. In this connexion it is interesting to note the reduced requirements for cortisone of the Addisonian patient who has become accustomed to a low level of circulating cortisol.

\section{(B) Catabolism}

Wilson (1956) has studied in considerable detail the corticosteroid metabolites in urinary extracts from two male rheumatoid arthritics and found them to be different in a number of respects from similar extracts from healthy men. The significance of her findings has yet to be determined. It has also been reported that after the administration of 11-desoxycortisol the pattern of the urinary metabolites differs as between rheumatoid arthritics and controls (Robinson, 1956).

A study of the quantitative output of a number of urinary $17-\mathrm{KS}$ in rheumatoid arthritis has not revealed any deviation from that of normal controls (Birke, 1954).

The findings most relevant to rheumatoid arthritis will be those of corticosteroid metabolism within connective tissues. Joint cavities are connective tissue spaces, and a start has been made in studying the metabolism of cortisol injected into normal and rheumatoid knees (Fairbanks and Wilson, 1956; Wilson, Fairbanks, Scialabba, McEwen, and Ziff, 1956). A marked difference was found between the metabolites recovered from the rheumatoid knees and those recovered from the controls. It remains to be discovered whether this difference is specific for rheumatoid inflammation.

\section{The Effect of Pregnancy}

Is it a change in corticosteroid metabolism in pregnancy that brings relief to some pregnant rheumatoid arthritics?

The study of the physiological changes that occur in association with remissions and relapses in the pregnancies and puerperia of rheumatoid arthritics is of outstanding interest and is surely one of the most promising subjects for our study.

What evidence is there of any increased output of cortisol during pregnancy?

The subject was expertly reviewed by Hills, Venning, Dohan, Webster, and Richardson (1954), and the conclusion was reached that there was no proof of an increased output of corticosteroids. From studies mentioned above it appears sound to assume that the amounts of cortisol metabolites appearing in urine as $17-\mathrm{KGS}$ or $17(\mathrm{OH}) \mathrm{CS}$ do reflect quantitatively the adrenal output of cortisol, but the observations on which this assumption is based did not extend to the pregnant state. At this Centre, one pregnant rheumatoid arthritic was given cortisone acetate throughout pregnancy and on twenty occasions 24-hour specimens were collected and assayed for $17-\mathrm{KGS}$. On $100 \mathrm{mg}$. daily the recoveries ranged from 35 to 38 per cent. and on $75 \mathrm{mg}$. from 34 to 45 per cent. These findings are within the normal range and so lend support to the assumption that the adrenal output of cortisol in pregnancy can be deduced from the urinary recoveries of $17-\mathrm{KGS}$ or $17(\mathrm{OH}) \mathrm{CS}$. If the output of $17-\mathrm{KGS}$ and $17(\mathrm{OH}) \mathrm{CS}$ in urine does reflect the adrenal output of cortisol in pregnancy what has been found? Assays made at this Centre show that there is an increase towards the end of pregnancy (Appleby and Norymberski, 1957), but not more than might be explained by the rising glomerular filtration rate of pregnancy (Evans, 1955; Sims and Krantz, 1956). (With a raised glomerular filtration rate more cortisol might have to be secreted to maintain the same blood level.)

Even if this increased excretion of $17(\mathrm{OH}) \mathrm{CS}$ does reflect an increase in available cortisol, it occurs too late in pregnancy to account for the remission in rheumatoid arthritis, and is in any case barely of sufficient magnitude to favourably affect even the 
mildest case. (We have found that corticotropin therapy must raise the excretion of $17(\mathrm{OH}) \mathrm{CS}$ more than 50 per cent. to produce any beneficial effect in rheumatoid arthritis.)

Plasma levels of "17-hydroxycorticosteroids".Here the position is entirely different. Early in pregnancy, when the remission in rheumatoid arthritis usually begins (Hench, 1949), the level rises considerably. It stays $200-400$ per cent. above the average non-pregnant level till term, and then slowly falls to normal in the first 2 weeks of the puerperium (Bayliss, Browne, Round, and Steinbeck, 1955; Gemzell, 1953; Robinson, Bernhard, Grubin, Wanner, Sewekow, and Silber, 1955). If this increase meant that 2 to 4 times as much cortisol was available for use one would expect all pregnant rheumatoids to have major remissions and all pregnant women to have signs of an early Cushing's syndrome by the ninth month. Study of the protein-binding of steroids (Eik-Nes, Schellman, Lumry, and Samuels, 1954; Daughaday, 1956) and of the disposition of steroids in body fluids (Abelson, Baron, and Toakley, 1955; Sandberg, Eik-Nes, Nelson, and Tyler, 1954) suggests that normally only some 5 per cent. of the plasma "17-hydroxycorticosteroids" can freely diffuse into the tissues, and that the amount of free cortisol and free cortisone (physiologically active) that appears in the urine may be a measure of this available cortisol.

What then is the output in the urine of free cortisone and cortisol during pregnancy?

De Courcy, Bush, Gray, and Lunnon (1953) estimated the amount in a small number of pregnant and non-pregnant women and found that the output was raised approximately 100 per cent. during pregnancy. That such a rise occurs has recently been confirmed in a larger series of pregnant women (Gray, 1957). This is consistent with the finding by bio-assay of raised levels of glycogenic steroids in the urine during pregnancy (Venning, 1946).

Here then is a plausible explanation of the ameliorating effect of pregnancy in rheumatoid arthritis. The apparent disparity between the increase in non-diffusable protein-bound "17-hydrocorticosteroids" and that which is freely diffusable suggests that the nature of the proteins that bind cortisone and cortisol may change during pregnancy. There is a precedent for this type of change in the protein-binding of thyroxine during pregnancy. The relation of these changes to the rate of destruction of cortisol in pregnancy and certain disease states and to the hormone levels in the tissues, is being studied by a number of research groups. As yet no clear picture has emerged. The fact that altera- tions in plasma protein can affect the levels of protein-bound hormones calls for a study of the proteinbinding of cortisol in rheumatoid arthritis.

There is some evidence that the plasma level of corticosterone is raised during pregnancy (Morris and Williams, 1953) and that the urinary excretion of aldosterone is increased (Martin and Mills, 1956), but neither corticosterone (Robinson, Wolfson, and Duff, 1952), nor aldosterone (Ward and Hench, 1955), have been found of value in the treatment of rheumatoid arthritis.

\section{Pregnancy in Addison's Disease}

One of the reasons stated for our interest in the metabolism of corticosteroids was that the pregnant state favourably affected both rheumatoid arthritis and Addison's disease. It would be reasonable to expect the Addisonian patient to deteriorate during pregnancy, because the disease is usually progressive and because pregnancy entails a considerable increase in metabolic activity. In consequence, any suggestion of improvement is of great interest. There are many references in the literature to the subject of amelioration of Addison's disease during pregnancy (Kaiser, 1956; Christy, Wallace, and Jailer, 1955; Baulieu, Bricaire, and Jayle, 1956; Samuels, Evans, and McKelvey, 1943; Knowlton, Mudge, and Jailer, 1949; Migeon, Prystowsky, Grumbach, and Byron, 1956; Jailer and Knowlton, 1950), but little recorded evidence in substantiation. Some authors may have in mind the increased survival of certain animals adrenalectomized during pregnancy. Crises in the puerperia (and not during labour) of Addisonian patients are emphasized (Fitzpatrick, 1922; Richards, 1952; Sheldon, 1945; Thorn, Dorrance, and Day, 1942), as is the evidence that pregnant Addisonian patients do better if allowed to go to term (Thorn and others, 1942; Zwanenberg, 1945). The author has personal knowledge of a patient who developed Addison's disease and subsequently survived three pregnancies (without cortisone). In the second half of each pregnancy she felt and looked better in herself and her blood pressure was improved. She died suddenly 2 days after a normal termination of the third pregnancy. Autopsy revealed a right upper lobe pneumonia, tuberculous pyelonephritis, and tuberculous destruction of both adrenals. Perkins (1932) described a patient who improved during pregnancy, and Samuels and others (1943) recorded a patient whose Addison's disease relapsed after pregnancy. The issue has been complicated since the advent of cortisone therapy, but Kaiser (1956) has expressed the opinion that "the clinical course of Addison's 
disease which has been adequately stabilized by cortisone therapy in the non-pregnant state is in no way adversely affected by pregnancy".

If it is found that there is an increase in available cortisone and cortisol during pregnancy which is not dependent upon any increased activity of the adrenal cortex, it would tend to confirm the clinical evidence cited above. But this is just what the evidence of a raised urinary output of free cortisone and cortisol and a normal output of $17(\mathrm{OH}) \mathrm{CS}$ in pregnancy suggests. It has been shown that, in the adrenal-deficient pregnant woman, the output of biologically assayable glycogenic corticoids rises (Hills and others, 1954); it remains to be shown that the material assayed is in fact cortisone and cortisol. Evidence of a raised plasma level of "17-hydroxycorticosteroids" in the pregnant Addisonian is conflicting (Jailer, Longson, and Christy, 1956; Baulieu and others, 1956). It is possible that the levels of both the free and protein-bound cortisone and cortisol could rise without there having been an increased production from the adrenal, since there is evidence that a great deal of cortisol can be reduced and disposed of before it has had a chance to affect the tissues generally. In fact, our assays of urinary $17(\mathrm{OH}) \mathrm{CS}$ may reflect the share of the liver in cortisol metabolism more accurately than the share of the tissues. The low recoveries of urinary $17(\mathrm{OH}) \mathrm{CS}$ after the intramuscular or intra-articular injection of cortisone acetate tend to confirm this (unpublished findings).

If the relief of rheumatoid arthritis and the amelioration of Addison's disease during pregnancy are due to an increased availability to the tissues of existing supplies of cortisol, why are not all patients relieved by pregnancy and why do not all Addisonian patients suffer from rheumatoid arthritis? The answer surely is that in rheumatoid arthritis there is a local factor as well as a humoral factor. The classical symmetrical involvement of all peripheral joints is the exception rather than the rule. Raising the local concentration of available cortisol may well enable the enzyme systems concerned to deal with the local breakdown. When the local defect is not too gross, it may be reversed. When it is too gross, further raising the levels of cortisol may interfere with other processes and add disease to disease. Before leaving this subject, it is of interest to note that rheumatoid arthritis may be unduly common in association with hypopituitarism (Sugar, 1953; Shrock, Sheets, and Bean, 1951; Gallavan and Steegmann, 1937). At autopsy and in the hospital ward, rheumatoid arthritis is often overlooked unless it is severe or is being looked for, so it is noteworthy that Sheehan (1939), in reviewing his syndrome, reported no less than thirteen of 96 cases as having "rheumatism of the knees".

\section{Corticosteroid Therapy}

The failure of cortisone to cure rheumatoid arthritis or even to do better than aspirin in the long run has led many to conclude that corticosteroid metabolism is not concerned in any way with the manifestation of the disease. There are a number of observations that cast doubt on this conclusion. It is common knowledge that in many rheumatoid patients the inflammation will subside and the stiffness disappear on a dose of cortisone that has no measurable effect on inflammation induced by infectious agents or on inflammation of an allergic nature (e.g. tuberculin allergy). The fact that after some months this effect may be lost does not necessarily mean that the disease has broken through a non-specific anti-inflammatory process. It may mean that the cortisone is being destroyed before it reaches the site of the lesions. The orally-administered steroid must all pass through the liver before reaching the tissues. As it does so in a concentration well above physiological levels, it may well be that the liver's ability to dispose of it increases with time. Two observations suggest this. One is that, if a patient has taken cortisone for a year or more and no longer appears to be deriving benefit from a dose of $75 \mathrm{mg}$., he will once more find relief if his dose is changed to an equivalent amount of delta-1 cortisone (i.e. $15 \mathrm{mg}$. prednisone). With prolonged experience of this structurally different steroid, his clinical response may once more diminish. The other observation is that when therapeutic amounts of cortisol are infused directly into the systemic circulation (i.e. not the portal circulation) continuously for several years, there appears to be no loss of clinical effectiveness (i.e. adaptation does not occur during prolonged stimulation of the adrenal cortex by corticotropin). Both these observations have been made on groups of rheumatoid arthritic patients at this Centre and as yet neither has been substantiated in print.

\section{Summary and Conclusions}

Knowledge of the secretion of corticosteroids and of certain aspects of their deployment and metabolism has been reviewed in relation to rheumatoid arthritis. No evidence has been found to suggest that there is a qualitatively abnormal secretion by the adrenal cortex in the disease, though present knowledge of this subject is far from complete. Deductions as to the quantitative secretion of cortisol 
are fairly firmly based. A study of the 24-hour secretion of cortisol (measured as total 17-hydroxycorticosteroids in urine $\times 2 \cdot 5$ ) of 124 rheumatoid arthritic patients revealed neither a deficiency nor an excess. What it did reveal was that the disease does not constitute a "stress" to the pituitaryadrenal system, since there was no correlation between disease activity (as measured by the erythrocyte sedimentation rate) and the output of cortisol. The question was therefore asked "does this in itself constitute a defect of the disease", and the subject was considered in the light of the effects of adrenal stimulation therapy.

Some of the deficiencies in our knowledge of the utilization and metabolism of the adrenocortical hormones were stated and it was concluded that, at the present time, various deviations from the normal could quite well go unnoticed. The abnormalities that have been reported in the metabolism of corticosteroids in rheumatoid arthritics were noted and the need for further research to determine their significance was emphasized. Alterations in cortisol metabolism during pregnancy and in their relation to pregnancy remissions in rheumatoid arthritis, and the reported amelioration of Addison's disease, were discussed. It was thought likely that the regression of signs and symptoms in pregnant rheumatoid arthritic patients was due to an increased availability of cortisol to the tissues and not to an increased output by the adrenal (or the products of conception).

Finally, consideration was given to the significance of the failure of cortisone (or cortisol) favourably to affect the disease in the long run. It was concluded as the result of certain observations, that this failure did not exclude the notion that cortisol plays a part in the manifestations of the disease or that it is a humoral factor concerned in the pathogenesis of the disease.

It has been assumed throughout that rheumatoid arthritis :s a single entity; this is customary since there is as yet no justification for any subdivision except on purely clinical grounds. Nevertheless, it may be surmised that in the purely local form the defect is essentially present in the tissues affected, whereas in the generalized form the humoral agents are more important. It is in this latter form that abnormalities in the deployment and metabolism of corticosteroids are most likely to be confirmed.

\section{REFERENCES}

Abelson, D., Baron, D. N., and Toakley, J. G. (1955). J. Endocr., $12,87$.

Appleby, J. I., Gibson, G., and Norymberski, J. K. (1955). Annals

of the Rheumatic Diseases, 14, 172.
,- , and Stubbs, R. D. (1955). Biochem. J., 60, 453.

, and Norymberski, J. K. (1957). J. Endocr. (in the press).
Avandano, L. H., Nelson, D. H., Crabbe, J., Ross, E. J., Renold, A. E.. and Thorn. G. W. (1956). J. clin. Endocr.. 16. 920.

Barry, M. C.. Eidinoff, M. L.. Dobriner, K.. and Gallagher, T. F. (1952). Endocrinology, 50, 587.

Baulieu. E. E.. Bricaire. H., and Jayle, M. F. (1956). J. clin. Endocr., 16. 690 .

Bayliss, R. I. S., Browne, J. C. McC., Round. B. P.. and Steinbeck. A. W. (1955). Lancet. 1. 62 .

Birke, G. (1954). Acta med. scand. Suppl. 291, p. 83.

Franksson, C., and Plantin. L. O. (1955). Acta endocr. (Kbh.), 18. 201.

Bongiovanni. A. M. (1954). J. clin. Endocr.. 14. 341.

Bush. I. E. (1953). Ciba Foumd. Colloq. Endocr.. 7, 210.

and Sandberg. A. A. (1953). J. biol. Chem.. 205. 783.

Christy. N. P.. Wallace. E. Z.. and Jailer. J. W. (1955). J. clin. invest. 34, 899.

Daughaday, W. H. (1956). Ibid.. 35, 1428.

De Courcy. C.. Bush. I. E.. Gray. C. H., and Lunnon. J. B. (1953). J. Endocr., 9, 401 .

Dobriner, K.. Lieberman, S.. Rhoads, C. P., and Taylor, H. C. (1948). Obstet. gynec. Surv.. 3, 677.

- - Wilson, H., Dunham, M., Sommerville, I. F., and Rhoads, C. P. (1951). "Proc. 2nd Clin. ACTH Conf.". ed. J. R. Mote, vol. 1, p. 56. Blakiston, New York.

Dorfman, R. I. (1955). In "The Hormones", ed. G. Pincus and K. V. Thiman, vol. 3, p. 589 . Academic Press, New York.

Eik-Nes, K.. Schellman, J. A., Lumry, R., and Samuels, L. T. (1954). J. biol. Chem., 206, 411 .

Empire Rheumatism Council (1950). Annals of the Rheumatic Diseases, Suppl. vol. 9, ed. E. Lewis-Faning.

Evans, T. N. (1955). Amer. J. Obstet. Gynec. 70, 122.

Fairbanks, R., and Wilson, H. (1956). Fed. Proc., 15, 249 (Abst. 811).

Fernando F. B. Personal communication.

Fitzpatrick, G. (1922). Surg. Gynec. Obstet. 35, 72.

Forsham, P. H., Di Raimondo, V., Island, D., Rinfret, A. P., and Orr, R. H. (1955). Ciba Found. Colloq. Endocr., 8, 299.

Gallavan, M., and Steegmann, A. T. (1937). Arch. intern. Med., 59, 865 .

Gemzell, C. A. (1953). J. clin. Endocr., 13, 898.

Gornall, A. G., Gwilliam, C., and Hall, A. E. D. (1956). J. clin. Endocr., 16, 950.

Gray, C. H. (1957). Personal communication.

Gulyassy, P. F. and Rinfret, A. P. (1956). J. clin. Endocr.. 16, 950.

Hellman, L., Bradlow, H. L., Adesman, J., Fukushima, D. K.. Kulp, J. L., and Gallagher, T. F. (1954). J. clin. Invest., 33, 1106.

- - - Frazell, E. L.. and Gallagher. T. F. (1956). Ibid., 35, 1033.

Hertoghe, J., Crabbe, J.. Duckert-Maulbetsch, A., and Muller, A. F. (1955). Acta endocr. (Kbh.). 20, 139.

Hench, P. S. (1949). Annals of the Rheumatic Diseases, 8, 90.

Hill, S. R. Holley, H. L.. Starnes, W. R., and Hibbett, L. L. (1956). Ibid., 15,69

Hills, A. G.. Venning. E. H., Dohan, F. C., Webster, G. D., and Richardson. E. M. (1954). J. clin. Invest. 33, 1466

Jailer, J. W., and Knowlton. A. I. (1950). Ibid., 29, 1430.

- Longnos, D., and Christy, N. P. (1956). Fed. Proc., 15. 100 (Abst. 323).

Kaiser, I. H. (1956). J. clin. Endocr., 16, 1251.

Klein, R.. Papadatos, C., Fortunato, J., and Byers, C. (1955). Ibid., $15,215$.

Knowlton, A. I.. Mudge. G. H., and Jailer, J. W. (1949). Ibid., 9.514.

Lampe-Hintzen, D. A. V. M., and Huis in't Veld, L. G. (1955). Ibid., 15, 1152 .

Marks, L. J., and Leftin, J. H. (1954). Ibid., 14, 1263.

Martin, J. D.. and Mills, I. H. (1956). J. Endocr. (in the press).

Migeon. C. J.. Prystowsky, H., Grumbach, M. M., and Byron, M. C. (1956). J. clin. Invest., 35, 488.

- Sandberg, A. A.. Decker, H. A.. Smith. D. F., Paul, A. C., and Sandberg. A. A., Decker, H. A.. Smith, D. F ̈6, 1137.

Morris C.J. O. R. and Williams, D. C. (1953). Biochem. J.. 54, 470 .

__ 24, (1955). Ciba Found. Colloq. Endocr., 8, 157

Nelson. D. H., and Samuels, L. T. (1952). J. clin. Endocr., 12, 519. Norymberski, J. K., Stubbs, R. D., and West, H. F. (1953). Lancet.

1, 1276.
Perkins, P. A. (1932). J. Amer. med. Ass., 99. 1500.

Peterson, R. E.. and Wyngaarden, J. B. (1955). Ann. N.Y. Acad. Sci, $61,297$.

__ (1956). J. clin. Invest., 35, 552.

Pincus, G. (1955). Ann. N.Y. Acad. Sci., 61, 283.

_- and Romanoff, E. B. (1955). Ciba Found. Colloq. Endocr., $8,97$.

Porter, C. C., and Silber, R. H. (1950). J. biol. Chem., 185, 201.

Querido, A.. Kassenaar, A. A. H., and Cats, A. (1955). Ciba Found. Colloq. Endocr., 8, 309.

Reddy, W. J. (1954). Metabolism, 3, 489.

Richards, T. A. (1952). Brit. med. J., 1, 421. 
Robinson, H. J., Bernhard, W. G., Grubin, H., Wanner, H., Sewekow, G. W., and Silber, R. H. (1955). J. clin. Endocr., 15, 317.

Robinson, W. D. (1956). Annals of the Rheumatic Diseases, 15, 71 , Wolfson, W. Q., and Duff, I. F. (1952). Ibid., 11, 313.

Samuels, L. T., Evans, G. T., and McKelvey, J. L. (1943). Endocrinology, 32, 422.

Sandberg, A. A., Eik-Nes, K., Nelson, D. H., and Tyler, F. H. (1954). J. Lab. clin. Med., 43, 874.

Schrock, C. E., Sheets, R. F., and Bean, W. B. (1951). J. clin. Invest., 30, 174 .

Sheehan, H. L. (1939). Quart. J. Med., 8, 277.

Sheldon, D. E. (1945). Amer. J. Obstet. Gynec., 49, 269.

Silber, R. H., and Busch, R. D. (1956). J. clin. Endocr. 16, 1333.

Silber, and Porter, C. C. (1954). J. biol. Chem., 210, 923 .

Simpson, S. A., and Tait, J. F. (1955). Rec. Prog. Horm. Res., 11, 183.

Sims, E. A., and Krantz, K. E. (1956). Clin. Res. Proc., 4, 142.

Sugar, M. (1953). J. clin. Endocr., 13, 1118.

Sweat, M. L. (1955). Ibid.. 15, 1043.

Abbott, W. E., Jeffries, W. McK., and Bliss, E. L. (1953). Fed. Proc., 12, 141.

Thorn, G. W., Dorrance, S. S., and Day, E. (1942). Ann. intern. Med., 16, 1053

Venning, E. H. (1946). Endocrinology, 39, 203.

Beck, J. C. Dyrenfurth, I., and Giroud, C. J. P. (1955). J. clin. Endocr., 15, 853 .

Ward, L. E., and Hench, P. S. (1955). Ann. N.Y. Acad. Sci., 61, 620. Weichselbaum, T. E., and Margraf, H. W. (1955). J. clin. Endocr., 15,970

West, H. F. (1953-54). J. Endocr., 10, xii.

West, and Newns, G. R. (1955). Lancet, 1, 578

Wilson, H. (1956). Annals of the Rheumatic Diseases, 15, 70.
, Fairbanks, R., Scialabba, D., McEwen, C., and Ziff, M. (1956). J. clin. Endocr. 16,86.

Zwanenberg, D. van (1945). St. Bart's Hosp. J., 49, 31

\section{Le métabolisme des corticostéroïdes et l'arthrite rhumatismale}

\section{RÉSUMÉ ET CONCLUSIONS}

On a passé en revue ce qu'on sait sur la sécretion des corticostéroïdes et sur certains aspects de leur déploiement et métabolisme en rélation à l'arthrite rhumatismale. On n'a pas trouvé de preuve indiquant qu'il y aurait une sécrétion qualitativement anormale par l'écorce surrénale dans cette maladie, mais nos connaissances actuelles de ce sujet sont loin d'être complètes. Les déductions concernant la sécrétion quantitative d'hydrocortisone ont une base assez ferme. Des études de la sécrétion d'hydrocortisone sur 24 heures (en fonction du chiffre total des 17-hydroxicorticostéroïdes dans l'urine multiplié par 2.5) chez 124 rhumatisants arthritiques n’ont révélé ni de déficit ni d'excès. On en a appris, par contre, que la maladie n"impose pas de "fatigue", au système surréno-pituitaire, puisqu'il n'y avait pas de corrélation entre l'activité de la maladie (en fonction de la vitesse de sédimentation érythrocitaire) et le débit d'hydrocortisone. On s'est démandé alors "est-ce que ceci en soi-même constitue un facteur morbide?" et on a considéré cette question à la lumière des effets de la thérapie par stimulation surrénale.

Après avoir relevé certaines lacunes dans nos connaissances de l'utilisation et du métabolisme des hormones cortico-surrénales, on conclut qu'à présent certaines déviations de la norme pourraient passer inaperçues. On nota les anomalies relevés chez les rhumatisants arthritiques en ce qui concerne le métabolisme corticostéroïde et on souligna la nécessité des recherches ultérieures pour déterminer leur importance. On discuta les altérations du métabolisme de l'hydrocortisone pendant la grossesse à propos des rémissions chez des femmes atteintes d'arthrite rhumatismale et de maladie d'Addison. On pense que l'atténuation des signes et des symptômes chez les rhumatisantes enceintes serait due à la disponibilité augmentée d'hydrocortisone au niveau des tissus et non pas à la production augmentée par la surrénale (ou par les produits de conception).
Finalement, on prit en considération la signification du fait que la cortisone (ou l'hydrocortisone) ne réussissait pas à influencer favorablement la maladie à longue échéance. On conclut, à la suite de certaines observations, que cet échec n'excluait pas la notion que l'hydrocortisone joue un rôle dans les manifestations de la maladie et qu'elle soit un facteur humoral dans la pathogénie de la maladie.

On a présumé ici que l'arthrite rhumatismale était une seule entité; on le fait d'usage puisque, pour le moment, des sous-divisions ne seraient justifiées que pour des raisons purement cliniques. Néanmoins, on peut bien concevoir que dans la forme purement locale le défaut se trouverait dans le tissu atteint, tandis que dans la forme généralisée les agents humoraux seraient plus importants. C'est dans cette dernière forme que les anomalies de déploiement et de métabolisme des corticostéroïdes pourraient bien se voir confirmées.

\section{El metabolismo de los corticoesteroides y la artritis reumatoide}

\section{SUMARIO Y CONCLUSIONES}

Se revistaron neustros conocimientos respecto a la secreción de los corticoesteroides y a ciertos aspectos de su despliegue y metabolismo en relación a la artritis reumatoide. No se encontraron pruebas de que en esta enfermedad la secreción por la corteza suprarrenal fuera cuantitativamente anormal, pero aún falta mucho para completar nuestros conocimientos sobre este sujeto. Las deducciones respecto a la secreción cuantitativa de la hidrocortisona tienen una base bastante sólida. La investigación de la secreción de hidrocortisona (medida por la cifra total de 17-hidroxicorticoesteroides $\times 2,5$ ) por 24 horas en 124 enfermos con artritis reumatoide no reveló deficiencia o exceso. Reveló, en cambio, que la enfermedad no impone una "fatiga" al sistema suprarreno-hipofisario, ya que no hubo correlación entre la actividad de la enfermedad (medida por la velocidad de sedimentación eritrocitaria) y la producción de hidrocortisona. Se puso entonces la cuestión "constituiría eso mismo un factor mórbido?" y se la consideró a la luz de los efectos de la terapia por estimulación suprarrenal.

Después de haber notado ciertas deficiencias en nuestros conocimientos acerca de la utilización y del metabolismo de las hormonas suprarrenales, se concluyó que en la hora actual ciertas deviaciones de lo normal pudieran pasar inadvertidas. Se notaron las anomalías encontradas en los artríticos reumatoides respecto al metabolismo corticoesteroide y se puso de relieve la necesidad de investigaciones ulteriores para determinar su significado. Se discutaron las alteraciones del metabolismo de la hidrocortisona durante el embarazo en relación a las remisiones en mujeres con la artritis reumatoide y con la enfermedad de Addison. Se cree que la regresión de los signos y síntomas en las embarazadas reumáticas se debería a la mayor disponibilidad de hidrocortisona en los tejidos y no a la producción mayor por las suprarrenales (o por los productos de concepción).

Finalmente, se tomó en consideración la significancia del hecho de que la cortisona (o la hidrocortisona) no pudiera influir favorablemente la enfermedad a termino largo. Se concluyó, a consecuencia de ciertas observaciones, que este fracaso no excluía la noción de que la hidrocortisona desempeñase un papel en las manifestaciones de la enfermedad y de que fuese un factor humoral en su patogenesis. 
Se postuló aquí que la artritis reumatoide sea una sola entidad; es habitual de hacerlo, ya que, en la hora actual, subdivisiones se justifican solamente por razones puramente clínicas. Se puede concebir, sin embargo, que en la forma puramente local el defecto se encuentre en el tejido afecto, mientras que en la forma generalizada las agencias humorales tengan mayor importancia. Es posible que las anomalías de despliegue y de metabolismo de los corticoesteroides se vean confirmadas en la forma generalizada. 